\title{
Jonas Gabrielsen \& Tanja Juul Christiansen 2010. Talens Magt. Indføring i mundtlig retorik. 2. udgave. Hans Reitzels Forlag. 191 sider. ISBN-10: 8741254546 ISBN-13: 9788741254548
}

Bogen udgør en lille indføring i det at holde en tale. Bogen er på 191 sider inklusiv litteraturliste og register med stikord. Der er 9 kapitler, der omhandler 1) den retoriske arv, 2) mundtlighedens natur, 3) den retoriske situation, 4) argumentation, 5) eksempelbrug, 6) ethos, 7) disposition, 8) sprog og 9) actio.

Bogen er velskrevet, og forfatterne anvender i stort omfang selv retorisk viden i opbygningen. Fx anvender de mange konkrete eksempler. Der gennemgås en lang række grundlæggende begreber, fx phronesis, arete og eunoia - at fremstå vidende, sympatisk og vise, at man vil det bedste. Alle sådanne forklaringer er veldisponerede og følger de regler, forfatterne selv giver for disposition. Og på tilsvarende måde lever forfatterne op til deres egne retoriske regler for eksempelbrug. Bogen har en lang række illustrative tekstbokse, og en række figurer er med til at skabe et klart overblik over de klassiske begreber, den såkaldte retoriske arv. For det er det, bogen langt hen ad vejen gerne vil, nemlig skabe et overblik over, hvordan de retoriske begreber skal forstås, og hvordan de skal kunne anvendes i praksis.

Titlen på bogen antyder noget om dens formål. Den hedder Talens Magt med undertitlen indføring i mundtlig retorik. Læseren må så forvente at få en indføring, en introduktion - og det gør læseren også. I titlen ligger dog også en præmis, nemlig at man kan få magt via tale, at talen har en magt. Det er tvivlsomt, om en sådan præmis holder. Diskurskritiske tilgange, fx Foucault, Fairclough og Bourdieu, afslører tætte sammenhænge mellem magt og sprog. Det, et menneske kan sige og komme igennem med, hænger tæt sammen med de sociale forhold og magt. At forfatterne til denne bog forholder sig ureflekteret til sådanne diskursive forhold ved at insistere på den retoriske tradition og arv, jf. kapitel 1, bevirker, at bogen som helhed i højere grad kommer til at fungere som en illustration på retorik end et argument for den.

Forfatterne følger deres egen selviscenesatte dagsorden ved at levere en indføring i retorik - dog uden at indskrive modargumenter. Og her kunne man spørge, om de så ikke, som de selv foreslår, kunne have gendrevet argumenter imod en retorik. Dette ser dog ikke ud til hverken at være i forfatternes interesse eller optik, selvom forfatterne under overskriften gendrivelse på s. 138 foreslår, at man bør anvende dispositionselementet at tilbagevise fejlopfattelser og mulige modargumenter. Da forfatterne i bogen lægger sig ud med nutidige diskurskritiske tilgange til sprog ved i titlen implicit og i bogen overordnet at argumentere for magt via rationel tilrettelæggelse af talen, så burde de have fulgt deres eget råd om gendrivelse. Hvis de havde fulgt deres egne råd, ville det have klædt deres argumenter for retorikken.

At indtage en mere kritisk eller reflekteret tilgang til retorikken ville ikke kun i deres egen optik have været bedre - det ville også styrke bogen og dens sigte, som netop er at kunne virke i praksis. Spørgsmålet er, om retorik, som bogen påstår, virker - eller om den ikke gør. Det ser ikke ud, som om det er, hvad forfatterne vil. Det, forfatterne vil, står i den sidste sætning i bogen: "Denne bog er kun første indledende skridt til at beherske talens magt. Næste skridt er at komme på talerstolen - igen og igen og igen.” Det var ikke, hvad vi fik at vide ud fra titlen, hvor det fremgik, at det netop var en bog om talens magt! Og selvom titlen er en tilsnigelse, så er præmissen for forfatteren den samme hele bogen igennem: Vi kan principielt få magt via tale og retorik, blot vi øver os tilstrækkeligt også.

Bogen handler om talens mekanik. Bogen handler om rette form, uanset substans. Er jeg socialist, så kan jeg bruge teknikkerne. Er jeg liberal, kan jeg gøre ligeså. Bogen forholder sig ikke til det lødige eller etiske i at bruge teknikker for at opnå sine mål, for at få magten. Den forholder sig ikke til autenticitet og moral, rigtigt og forkert - ej heller til sin egen præmis, at retorik virker. 
Bogen handler i stedet om at viderebringe den retoriske arv, jf. kapitel 1, og det for enhver pris. At det handler om form og at se ud som, det vidner mange eksempler på. I bogen henvises til Aristoteles og de forskellige overbevisningsformer. Målet er at overbevise og ikke at reflektere over, hvad man overbeviser om. Det pointeres også, at sproget kan forføre (s. 22).

”Dernæst er det vigtigt at være sig bevidst, at det er publikum, der skal overbevises, ikke en selv. Målet er altså at analysere sig frem til, hvad der vil virke overbevisende på det givne publikum, frem for at tage afsæt i det, man som taler selv finder overbevisende.” (S. 58, min fremhævelse).

Ikke blot insisterer forfatterne på et antikt sprogsyn, hvor sprogbrugerne ikke udvikler sig og forandrer sig samtidig med, at de taler. Nej, forfatterne sætter sig også ud over almindelig etik og moral, for det er for dem helt ligegyldigt, hvad taleren egentlig skulle mene eller oprigtigt stå inde for, blot det er i det retoriske formåls retning. På den måde bliver sprogbrug ikke en erkendelsesmæssig aktivitet, men blot overbevisningsmekanik. Det kan godt være, at denne teknologi så flot i bogen omtales som kunst (s. 11). Ikke desto mindre er målet ikke, hvad der grundlæggende vil overbevise, fordi der er substans i det, men vil virke som overbevisende.

Denne formmæssige tilgang, hvor fokus er, hvad der virker som og ser ud som noget, udgør en gennemgående optik i bogen. Især i kapitlet om troværdighed gør forfatterne meget ud af at forklare, hvordan man skal fremstå. "Det handler om at fremstå som en person med kompetencer på lige præcis det område, talen handler om...” (s. 116, min fremhævelse). ”Vi vælger at udlægge arete som et spørgsmål om at fremstå sympatisk...” (s. 118, min fremhævelse af at fremstå). På side 120 taler forfatterne om, at taleren kan komme til at fremstå irettesættende, og det bør han ifølge dem undgå (min fremhævelse). Der drøftes ikke her, om det også kunne være berettiget, at taleren var irettesættende eller kunne være det, og om det kunne have en funktion, at han var det, og at det også virkede sådan. Det er også vigtigt for forfatterne, at man ikke kommer til at fremstå som om, man mangler indsigt i emnet (s. 121), uanset at det i en helt anden optik kunne forekomme ret autentisk og sympatisk, såfremt en offentlig person accepterede sin manglende viden og faktisk autentisk agerede ud fra det. For forfatterne gælder det om, at taleren fremstår som åben, smilende, engageret og imødekommende, og ikke om taleren faktisk er det (s. 121-122).

I tekstboksen side 123 opsummeres ethos-dyderne i samme optik: Man skal fremstå vidende og indsigtsfuld, man skal fremstå sympatisk. Det er vigtigt, at talen fremstår fokuseret (s. 125). For forfatterne er det ligegyldigt, hvad taleren skulle mene, og denne optik giver dem problemer i sidste kapitel, hvor der tales om kunsten at fremføre sin tale. En opdateret og moderne optik på kropssprog vil tage udgangspunkt i begrebet autenticitet. Har man som menneske selv arbejdet med et emne eller fagligt område, får man uvilkårligt et ejerskab til det. Det, man siger, er noget, man mener. Som engageret menneske har man sat sig ind i tingene, forstået og erkendt. Sprog og krop hænger sammen. Det hjertet er fuldt af, løber munden over med. Er man selv overbevist om noget, så bliver andre det også ved at se en fortælle entusiastisk om det, eller ved at se en holde en engageret tale om det. Taleren behøver ikke tænke på, hvordan han eller hun står. Og skulle man komme til at stå lidt akavet, kan det hos publikum ses som et sympatisk og autentisk træk, at nu personen taler om sit emne, så huer det ikke taleren helt, at der lige er noget, der skal formuleres og nytænkes undervejs. Tale og sprogliggørelse er spontan - og kropssproget korrelerer med det sagte.

I modsætning til dette gør forfatterne sig en del overvejelser, for hvad hvis kropssproget kommer til at signalere noget forkert? Den gode kropsholdning er vigtig: Man må ikke fremtræde overspændt eller underspændt (s. 166). Vejrtrækningen skal være velfungerende - og man må ikke signalere nervøsitet eller slaphed (s. 167). Fødderne skal placeres korrekt, ligeså knæ, ryg og bryst (s. 168-169). Og i kapitlet følger råd til mimik, auditive virkemidler og tempo, tryk, pauser, volumen og artikulation. Alle disse problemer ville forfatterne være foruden, såfremt de antog den præmis, at blot taleren er engageret og inde i sit emne, så vil kropssproget følge af sig selv. Kan denne manglende præmis hos forfatterne være, at de har den modsatte, nemlig at taleren ikke er inde i sit stof, ikke er engageret og ikke selv har en dyb forståelse af det? Der kunne argumenteres for dette. Alt andet lige vil en tilgang til sprogbrug og taler, hvor præmissen er, at taleren ikke skal 
tænke på, hvordan han fremstår, men på hvad han mener, være langt mere sympatisk. Mere vigtigt er, at forfatterne, såfremt de havde forholdt sig til sådanne modargumenter i deres egen retorik, ville have fremstået langt mere overbevisende.

Når alt kommer til alt, så har forfatterne til en vis grad ret i, at retorik virker. Retorik virker, fordi vi i vores kultur har konventioner for, hvordan man fremlægger sine synspunkter. En god disposition virker ikke, hvilket bogen kunne tages til indtægt for, fordi den er særlig logisk eller struktureret. Den virker i stedet, fordi vi har konventioner for, hvordan emner og stof disponeres. Bliver vi tilsvarende fascinerede over en tretrinsraket-fremførelse, så er det ikke fordi, den rent logisk eller følelsesmæssigt appellerer til noget dybt i os, men fordi vi har konventioner for, hvornår noget virker, og noget ikke virker.

Sådanne teknikker har vi alle god grund til at kende til, overalt i skole- og uddannelsessystemet. Skal vi lære om det, skal vi også lære, hvad retorik ikke kan. Retorik kan ikke få os til at erkende noget eller få andre til at erkende noget. Retorik er en særlig tilrettelæggelse af sprog og udgør samtidig et sæt af konventioner, som man bør lære eksplicit at forholde sig til. Dette aspekt er meget lidt tilstede i bogen.

Bogen fungerer godt som en foreløbig introduktion til basale retoriske greb, som alle tekstproducenter - uanset om det er mundtligt eller skriftligt - har brug for at kende til. De har også brug for at kunne forholde sig til det. Denne del klarer bogen meget dårligt. Uanset, at bogen modererer sin ambition i den sidste sætning, så er den skjulte præmis, at retorik virker. Det kan der sættes spørgsmålstegn ved - også om retorik virker godt nok.

Bogen viser i form og indhold, hvad den kan - på godt og ondt. Langt hen ad vejen er den uklar i sin egen retorik, for den er upræcis. Når politikeren upræcist fortæller, at vi skal løse problemerne på den bedst mulige måde, så har vi et godt eksempel. Og det er netop på den måde, forfatterne fortæller bogen igennem: Man skal have et godt kropssprog, et klart sprog (s. 25). Når man taler, skal man være konkret og gentagende (s. 32). Man skal komme med få pointer og information (s. 34). Man skal bruge simple, korte sætninger (s. 42). God retorik afhænger af situationen (s. 43). Talen må ikke indeholde for mange argumenter (s. 88). En afslutning må ikke være for lang (s. 143).

Det er vel retorik i en nøddeskal - for hvem vil påstå, at man skal have et uklart sprog, at retorik ikke afhænger af situationen, at talen skal indeholde for mange argumenter. Det er retorik, og det er uklart, for hvad er kriterierne for godt kropssprog, for konkret sprogbrug, for få pointer og for for mange argumenter. Spørgsmålet er også, hvad en for lang afslutning er. Og spørgsmålet er, om nogen vil påstå, at man skal lave en for lang afslutning.

Retorikken fungerer muligvis inden for de rammer, den selv sætter op. Bogen kommer til at pege på sine egne styrker og svagheder. Bogen gennemgår i god retorisk stil de retoriske grundbegreber og følger stort set selv de råd og vink, den giver. Tale sig til magt, det kan man næppe, og ved at insistere på det kommer bogen utilsigtet til at pointere, at retorik er en særlig veltilrettelagt sproglig illusion.

\section{Litteratur}

Bourdieu, Pierre 2001: Af praktiske grunde. Omkring teorien om menneskelig handlen. Hans Reitzels forlag. Fairclough, Norman 2008: Kritisk diskursanalyse. En tekstsamling. Hans Reitzels forlag.

Foucault, Michel 1971: Talens forfatning. København: Rhodos.

Carlo Grevy 